\title{
TESIS, ANTITESIS, DAN SINTESIS TERHADAP AGAMA
}

\author{
Frederikus Fios \\ Character Building Development Center, BINUS University \\ Jln. Kemanggisan Ilir III No. 45, Kemanggisan - Palmerah, Jakarta 11480 \\ Fios2013@yahoo.co.id
}

\begin{abstract}
From the beginning until now, religion has always been a paradoxical term. Religion has become an ambiguous term because it has both thesis and antithesis that are closely inherent. The thesis is that religion is positive strength striving for virtue, salvation, prosperity, happiness, and peace in the reality of human society globally and locally. On the other hand, religion also appears as negative force to be the antithesis of the religion itself. Problems rise on the religion lie not in the thesis but in the antithesis because thesis and antithesis are always accompanying the dynamics of religion in society reality. So that, it needs a "third way" as a tool to harmonize, align, and reconcile the contradiction. Research used qualitative method with critical hermeneutic approach intended to evaluate the antithesis of religion and show constructive side towards a better future. Based on the results and discussion, there is one thing called synthesis of religion. The synthesis area of religion should be an element that continues to be explored and optimized in order to create peace in the contemporary world and in the future. It takes an appreciation of positivistic religion so religion really becomes a force to liberate human beings from various negative phenomena which discolour the realm of religion.
\end{abstract}

Keywords: thesis, antithesis, synthesis, religion

\begin{abstract}
ABSTRAK
Dari dahulu hingga kini agama selalu merupakan terminologi paradoksal. Agama menjadi suatu istilah yang ambigu karena memiliki tesis dan antitesis yang melekat erat (inheren) padanya. Tesisnya adalah bahwa agama merupakan kekuatan positif yang selalu mengikhtiarkan kebaikan, keselamatan, kesejahteraan, kebahagiaan, dan situasi damai dalam realitas masyarakat manusia baik pada tataran global maupun lokal. Di sisi lain agama juga tampil sebagai kekuatan negativistik sebagai antitesis dari agama itu sendiri. Masalah yang muncul dalam kiprah agama sepanjang hidup manusia, bukan terletak pada tesisnya, melainkan pada sisi antitesisnya. Karena tesis dan antitesis selalu menyertai dinamika agama dalam realitas masyarakat, dibutuhkan jalan ketiga sebagai tools yang mengharmoniskan, menyelaraskan, dan mendamaikan kontradiksi ini. Penelitian menggunakan metode kualitatif dengan pendekatan hermeneutik-kritis, yang bermaksud mengevaluasi sisi antitesis agama dan menunjukkan sisi konstruktif menuju masa depan yang lebih baik. Berdasarkan hasil dan pembahasan, muncul hal yang disebut sintesis atas agama. Wilayah sintesis atas agama seharusnya merupakan unsur yang terus dieksplorasi dan dioptimalkan kiprahnya dalam usaha penciptaan tatanan perdamaian dalam dunia kontemporer dewasa ini hingga ke depannya. Penghayatan agama yang positivistik dibutuhkan sehingga agama sungguh menjadi kekuatan yang membebaskan manusia dari berbagai fenomena negatif yang mempolusikan ranah agama.
\end{abstract}

Kata kunci: tesis, antitesis, sintesis, agama 


\section{PENDAHULUAN}

Tulisan ini menyoroti kiprah agama dalam menciptakan perdamaian dunia global. Tulisan ini juga merupakan refleksi lanjut pascaprogram "Workshop Kerukunan Beragama Dosen-Dosen Pendidikan Agama se-DKI Jakarta" di Cisarua, Bogor belum lama ini. Menurut penulis, walaupun acara ini telah berlalu, pesan aktual dalam konteks peran agama menciptakan keharmonisan dunia global rasanya tetap bergaung dan relevan hingga sekarang bahkan sampai masa depan. Tulisan ini memberikan semacam gugatan terhadap kiprah agama agar terus menunjukkan peran positifnya dalam menciptakan peradaban manusia dan perdamaian global yang lebih baik.

Sudah menjadi aksioma umum bahwa dunia manusia berkembang pesat dari waktu ke waktu. Dunia berkembang cepat tanpa pernah bisa dikendalikan arahnya oleh manusia. Kekuatan teknologi informasi dan komunikasi menjadi media utama yang mempercepat laju perkembangan berbagai pihak yang getol mempromosikan bisnis, ekonomi, budaya, produk industri hingga berbagai mode dan atribut pelengkap gaya hidup. Globalisasi dalam berbagai aspek kehidupan menjadi suatu keniscayaan.

Di tengah mainstream (arus utama) globalisasi, spiritualitas hidup keagamaan manusia pun ikut berubah dalam konstelasi dan paradigma penghayatannya. Sebuah tren global terorbit, yang disadari ataupun tidak, menggeser peran agama dalam realitas sosial manusia. Setidaknya ada tiga kelompok penganut agama dalam realitas global masa kini.

Kelompok pertama adalah kelompok yang menghayati agama secara tradisional-radikal. Kelompok ini tertutup dan menjaga diri untuk tidak terkontaminasi dengan arus perkembangan global yang terjadi di sekitar lingkungannya. Akibatnya mereka antipati dan masa bodoh dengan arus globalisasi yang ada. Mereka cenderung mencari kebahagiaan di dalam aktivitas ibadat/ritual agama tanpa mau terlibat dalam isu-isu sosial masyarakat. Mereka cenderung tinggal dalam romantisme agama/spiritual tanpa mau aktif terlibat dalam perjuangan sosial masyarakat global mengatasi isu-isu aktual yang ada. Dalam paradigm ideologi agama, kelompok ini bisa dikategorikan sebagai kelompok beragama yang cenderung ke arah eksklusivistik.

Kelompok kedua merupakan kelompok yang sedikit/lebih terbuka terhadap kemajuan namun belum sepenuhnya melepaskan diri dari nilai-nilai tradisi agama yang dianutnya. Kelompok ini bersikap netral terhadap arus globalisasi yang ada dan tidak sampai mempersalahkannya. Mereka menghayati nilai-nilai tradisi agama namun terbuka juga pada hal-hal positif yang dibawa oleh globalisasi dunia. Mereka bisa disebut sebagai kelompok penganut agama yang moderat (berada di antara yang tradisional dan modern). Kelompok ini bisa dikategorikan sebagai kelompok orang beragama yang cenderung ke arah inklusivistik.

Kelompok ketiga, kelompok penganut agama postmodern (kontemporer) yang sedang atau bahkan sudah melepaskan diri dari ikatan nilai-nilai agama yang membelenggu hidup mereka. Dalam tataran ideal, mereka mengklaim diri sebagai penganut agama tertentu, tetapi sebetulnya secara praktis lebih suka melepaskan diri dari pengaruh agama dan cendreung mencari kebahagiaan dalam aktivitasaktivitas sosial masyarakat manusia. Kelompok ini cenderung memperjuangkan nilai-nilai spiritual, etika, humanisme, kebebasan, ekologi tanpa memasukkan diri ke agama tertentu. Mereka memiliki kesadaran akan realitas perbedaan dalam penghayatan agama/spiritual yang ada dan menerima kemajemukan. Namun demikian, mereka tidak menghayati agama secara eksklusif ataupun inklusif. Mereka cenderung ke arah profanisme, trendi, dan gaya ketimbang menghayati secara konsisten nilainilai religius secara ketat.

Kemunculan tiga paradigma penghayatan agama/spiritual dalam masyarakat dunia global tidak dapat disangkal. Fenomena ini menunjukkan bahwa agama telah mengalami erosi peran dalam 
diri manusia khususnya di kalangan para penganutnya. Konsekuensi logisnya, peran agama secara nyata bagi kebaikan dunia global tampak kabur, samar-samar dan tidak jelas. Hal ini berpotensi membuat peran agama makin tenggelam di tengah derasnya arus globalisasi. Lama-kelamaan agama hanyalah menjadi sebuah praktik formalisme belaka (tanda identitas personal) daripada penghayatan nilai intrinsik yang memiliki relevansi aktual bagi kehidupan/kemanusiaan universal khususnya penciptaan tatanan dunia yang harmonis-damai.

Masalah yang disoroti dalam tulisan ini yakni hal-hal negatif yang muncul dari penghayatan agama yang inklusivistik (antitesis) dikontraskan dengan hal-hal positif (eksklusivistik) yang inheren di dalam agama. Kemudian sebuah sintesis antara antitesis dan tesis dikonstruksikan menuju sebuah sinergi positif dalam praksis agama menuju penciptaan perdamaian dunia yang lebih ideal. Dengan demikian, tulisan ini bertujuan untuk menunjukkan sisi konstruktivisme agama yang seharusnya (das sollen) memuara pada penciptaan tatanan sosial masyarakat yang harmonis-seimbang dan menuju perdamaian sejati.

\section{METODE}

Artikel menggunakan metode kualitatif. Tulisan dikembangkan dengan menggunakan teknik kajian dokumentasi yakni berupa observasi dari buku dan artikel yang membahas topik relevan dengan tema tulisan ini. Nuansa hermeneutik-kritis sangat kental terasa dalam tulisan ini. Artikel mencoba untuk membangun sebuah paradigma ideal untuk mereaktualisasikan kembali kiprah agama yang sesungguhnya dalam dunia dewasa ini dan menunjukkan sisi aktual peran relevan agama yang perlu dimainkan dalam tatanan dunia menuju ideal agama yang makin positif dan beradab. Kajian ini membahas agama sebagai realitas sosial lalu disusul dengan meneropong isu aktual yang menantang peran agama dan pada bagian terakhir dikaji secara kritis-filosofis reaktualisasi peran agama dalam menciptakan perdamaian global. Bagian penutup merupakan simpulan dari artikel ini.

\section{HASIL DAN PEMBAHASAN}

\section{Tesis Agama: Kekuatan Positif dalam Realitas Sosial}

Terminologi agama memiliki banyak makna tergantung latar belakang ilmu dan paradigma pikir manusia. Dalam ranah praksis agama dikaitkan dengan hubungan manusia dengan kekuatan transenden yang melampaui daya pikir indrawi manusia. Istilah agama merujuk pada anasir yang berkaitan dengan institusi atau organisasi religius yang mengatur hubungan rohani-spiritual antara manusia dengan Tuhan sebagai Substansi Ilahi, Yang Adikodrati, Yang Maha Esa, Causa Prima.

Walaupun dunia terus berkembang disertai pesatnya teknologi dan ilmu pengetahuan, agama masih saja mendapatkan tempat dan ruang di dalam diri manusia. Data membuktikan bahwa agama terus berkembang di dunia ini dari waktu ke waktu. Orang beragama berjumlah lebih banyak dari kelompok orang tidak beragama. Hanya sekitar $12 \%$ saja dari penduduk bumi yang tidak beragama (Religious Tolerance, n.d.). Fenomena ini mengindikasikan agama masih berpengaruh signifikan secara khusus-personal dan secara komunal-sosial. Agama menjadi realitas sosial masyarakat yang berpengaruh dalam tatanan dunia di samping kiprah sains dan teknologi.

Lazimnya, agama menunjukkan suatu kondisi intensitas dan kualitas hubungan ideal antara manusia dengan Tuhan sebagai sumber eksistensi segala ada. Pencipta dunia disebut sebagai "Yang Ada”, "Yang Absolut", "Yang Mutlak" (Prawironegoro, 2010). Tuhan diakui oleh manusia sebagai 
Substansi/Zat yang menentukan segala ada dalam dunia. Tuhan diyakini sebagai Sang Ada Primer, Ada Pertama yang mengadakan ada sekunder lain di dalam kosmos (universum). Tuhan disebut Causa Prima, Penyebab Pertama segala ada. Penyebab Pertama ada dan berada dari diriNya sendiri. Adanya Sang Ada tidak diadakan oleh ada yang lain. Karena jika Tuhan diadakan oleh ada yang lain, Adanya Tuhan tidak mutlak atau bukan Maha Ada. Padahal Tuhan hakikatnya adalah Ada Absolut atau Ada Murni dari diriNya sendiri. Inilah filosofi dan keyakinan dasar penganut agama di Bumi ini. Filosofi ini diyakini penganut agama sebagai kebenaran iman tidak terbantahkan. Kebenaran ini menjadi alasan penting bagi manusia untuk tetap menghayati iman kepada Tuhan dalam ziarah eksistensi di atas panggung kehidupan ini.

Ribuan tahun silam negarawan tersohor Romawi Kuno, Marcus Tullius Cicero (106-43 SM) menyebut agama sebagai hukum alam tertinggi di dalam alam semesta ini. Agama, menurutnya, adalah hal yang diabdi dan disembahsujudi manusia dan yang disebut hukum alam yang lebih tinggi, supranatural dan ilahi (Storig, 1995). Definisi ini menegaskan 3 unsur cakupan dasar pembentuk agama yakni manusia atau subjek, kultus atau ritus, dan kekuasaan supernatural. Segala bentuk wacana terkait agama harus mencakup ketiga hal tersebut. Sosiologi, antropologi, psikologi, politik, metafisika, tata adat, fisika, kebudayaan, ilmu spekulatif termasuk unsur-unsur dan bidang konstitutif pemahaman tentang agama. Maka, agama harus dibaca dan dipahami dalam konteks pandangan spiritual manusia dan masyarakat tertentu.

Agama menunjukkan sikap keterbukaan manusia terhadap hal-hal yang lebih besar dan agung dari dirinya dan kemampuan manusia sendiri. Agama menunjukkan sikap keterbukaan manusia terhadap Kebenaran Absolut (mutlak) yang melampaui kondisi manusia sebagai kebenaran relatif. Agama sebagai ekspresi keterbatasan manusia dalam memahami diri dan dunianya. Agama menunjukkan adanya rasa ketergantungan manusia dalam ziarah hidupnya. Agama merupakan penegasan spontan manusia akan kekurangan dan keterbatasan dirinya. Agama merupakan kemampuan manusia untuk menyatakan: saya tahu, bahwa saya tidak tahu tentang segala sesuatu (Woi, 2001). Agama menunjukkan pengakuan manusia akan ketidaktahuan dan ketidakmampuan dirinya. Agama menunjukkan bahwa manusia adalah makhluk tidak benar dikonfrontasikan dengan Tuhan sebagai Substansi Maha Benar.

Suka atau tidak, fakta telah membuktikan hingga kini agama masih digandrungi banyak penduduk di bumi. Agama masih menjadi primadona yang menarik perhatian banyak orang yang meminati dunia religius-spiritual. Agama masih mengkristalkan dalam dirinya sesuatu yang mempesona, eksotis dan menarik perhatian. Di samping agama, terdapat juga aliran spiritualisme dan kebatinan yang fokus mengembangkan diri melalui meditasi, yoga dan aktivitas pertapaan dalam mengembangkan relasi eksklusif-intensif dengan Tuhan, Substansi Transenden itu. Pencarian akan Tuhan membuat manusia terus mengembangkan diri dalam aspek logika, emosi, dan tindakan gestikulatif untuk mencari hakikat kebenaran Tuhan.

Agama sangat penting bagi kehidupan sosial masayarakat global. Dalam konteks kontinen Asia, Eropa, Amerika dan Afrika, agama masih menjadi institusi penting dan dasar yang berfungsi mengatur dan menstabilkan kondisi sosial masyarakat. Sejalan dengan akar katanya, $a=$ tidak dan gama = kacau, agama meneguhkan kiprah sejatinya sebagai institusi yang menjaga harmoni bersama dan perekat kohesivitas sosial masyarakat global. Di sini agama muncul dengan kekuatan idealnya sebagai alat perdamaian bagi masyarakat manusia, bukan malah sebaliknya.

Pertanyaan aktual yang kerap menggugat peran dan fungsi agama dewasa ini yakni ketika fakta konflik antarmanusia terus terjadi, perang tak pernah usai, terorisme atas nama agama tak pernah berhenti dan berbagai gesekan terus terjadi secara sporadis di seantero belahan dunia ini. Indonesia masih tergolong negara dengan kasus intoleransi agama yang tergolong tinggi. Malah Indonesia pernah ditegur oleh dunia luar karena prestasi luar biasa dalam kasus intoleransi ini. Hal ini patut membuat malu dan berbenah diri. Berhadapan dengan fakta negatif ini, hal yang dapat dilakukan 
agama dalam mengatasi isu-isu kontra humanisme dan kontraperdamaian ini merupakan sebuah pertanyaan retoris yang patut diajukan pada orang beragama di dunia termasuk di bumi Indonesia tentunya. Sering kali justru para pencipta konflik dalam masyarakat global disinyalir diprovokasi oleh orang-orang yang mengaku beragama dan beriman pada Tuhan. Di sini agama mengandung dualisme di dalam dirinya. Agama berwajah ambigu dan ambivalen. Di satu sisi agama berperan menciptakan harmoni sosial, tetapi di sisi yang lain agama justru menjadi sarana bagi oknum tertentu untuk melakukan tindakan-tindakan disharmoni dalam realitas masyarakat manusia.

Positivisme agama menunjukkan peran sentralnya dalam mengatur hidup dan mengarahkan manusia untuk beriman pada Tuhan dan menghayati hidup etis-normatif. Agama menyatukan orang dengan latar belakang etnis dan profesi berbeda untuk tunduk dan hormat pada Tuhan. Di sini agama tampil sebagai alat untuk menciptakan perdamaian sosial. Sedangkan sisi negatif agama tercuat dalam fenomena perilaku sosial destruktif yang mengatasnamakan agama. Muncul politisasi agama (agama dipolitikkan) untuk kepentingan picik-negatif segelintir orang. Di sini agama tidak saja membawa hal positif bagi masyarakat, tetapi juga menciptakan masalah dalam realitas sosial. Perlu ditegaskan bahwa yang salah bukan agamanya, tetapi orang yang menghayati agamanya yang salah atau keliru. Agama sudah benar, yang belum benar terletak pada manusia yang beragama.

\section{Antitesis Agama: Fenomena Negatif dalam Realitas Sosial}

\section{Konflik Horizontal Berlabel Agama}

Sudah menjadi sebuah fakta dewasa ini yaitu bahwa konflik bermotif agama masih menjadi hal yang terjadi dalam realitas sosial. Perbedaan keyakinan, iman, tradisi religius, doktrin menjadikan orang beragama menghayati agama secara eksklusif dan memicu konflik antarpemeluk agama. Kondisi ini makin diperparah dengan munculnya kelompok radikalistis atau fundamentalistis yang makin menggelisahkan tatanan sosial masyarakat kita.

Konflik horizontal agama terjadi ketika konflik itu melibatkan kelompok penganut agama yang satu dengan penganut agama yang lain. Jenis konflik ini terjadi pada aras masyarakat pemeluk agama di akar rumput (grass groot). Sering hanya karena hal sepele dan sederhana saja, konflik antarpenganut agama mudah sekali disulut. Belum ditambah lagi dengan adanya pihak-pihak tertentu yang memprovokasi kelompok agama bersangkutan untuk berkonflik dengan sesama yang beragama lain. Intensitas konflik makin mendalam ketika rasa benci makin kuat dan bertambah dalam di antara kelompok pemeluk agama berbeda.

Konflik antarpemeluk agama sering dipicu juga oleh rasa kecemburuan sosial, tingkat kesejahteraan/kesenjangan sosial dan klaim eksklusivisme kebenaran iman oleh masing-masing pemeluk agama. Hal ini ditambah lagi rendahnya kualitas pendidikan yang menyebabkan orang tidak bisa berpikir rasional lagi. Semangat untuk saling meniadakan dan menyingkirkan mudah disulut dan menjadi-jadi.

Konflik horizontal menunjukkan bahwa umat pemeluk agama di dunia ini belum matang (dewasa) dalam menghayati imannya akan Tuhan. Ketidakmatangan ini menunjukkan adanya kegagalan para tokoh agama sendiri dalam membina iman umat menuju kematangannya. Para pemimpin agama tidak bisa lepas tangan dari tindakan tidak dewasa yang dilakukan oleh para penganutnya. Malah dikatakan bahwa para pemimpin agama ikut bertanggung jawab atas terjadinya konflik yang ada. Apalagi jika para pemimpin agama sendiri tidak cukup memiliki sikap eksklusif dalam menghayati imannya secara baik dan ideal. Oleh karena itu, konflik agama ini perlu menjadi titik fokus semua pihak yang menjadi bagian dari agama mulai dari pemimpin hingga umat penganut agama. 
Tingginya kasus toleransi agama di Indonesia bahkan menjadi perhatian presiden dan wakil presiden RI. Boediono sendiri pernah mengatakan dalam salah satu kesempatan perayaan keagamaan bahwa kasus toleransi di Indonesia masih saja memprihatinkan. Dikatakannya, PBB selalu menyoroti kasus toleransi di Indonesia dan ada banyak negara yang mempertanyakan munculnya kasus intoleransi yang makin sering muncul belakangan ini. Hal ini tentu makin menurunkan citra dan reputasi Indonesia di mata internasional.

Konflik menunjukkan bahwa toleransi masih belum ideal di Indonesia. Toleransi masih saja menjadi masalah. Magnis Suseno pernah melansir soal fanatisme picik berdasarkan agama yang disalahmengertikan orang Indonesia sebagai akar masalah intoleransi. Magnis mencontohkan menyalami saudara sebangsa beragama lain pada hari raya agama pun dianggap haram, tidak boleh. Ini makin menambah jarak antarpemeluk agama yang satu dengan yang lain. Rasa curiga makin bertambah dan meluas. Kondisi ini tidak sehat dalam konteks toleransi yang ideal.

Dalam ranah internasional kasus bernuansa agama tak kalah menariknya. Belakangan muncul rangkaian kasus bernuansa agama di Norwegia, Myanmar, Amerika, dan beberapa belahan dunia lain yang menunjukkan bahwa konflik bernuansa agama telah menjadi masalah global berbagai negara dunia. Hal ini menunjukkan bahwa agama mengandung unsur kontradiktif di dalamnya yang patut disadari dan diwaspadai bersama oleh semua negara dunia. Namun bagaimana pun juga fenomena negatif ini telah memberikan sinyal adanya bahaya yang ditebarkan agama dalam realitas sosial masyarakat kita baik secara nasional maupun internasional.

\section{Terorisme Global Bermotif Agama}

Salah satu cuatan ekstremisme penganut agama tampak dalam aksi teror yang menciptakan ketakutan psikologis bagi masyarakat luas. Munculnya beberapa tindakan teror yang meluas hampir di semua negara dunia termasuk Indonesia makin menciptakan kepanikan massal di kalangan masyarakat, ditambah dengan tayangan dan ekspos media massa yang makin menambah kondisi. Apalagi jika media disusupi oleh kepentingan ideologis tertentu (vested interested) yang negatif alias kontraproduktif. Media pun akhirnya membangun kenyataaan yang seolah-olah lebih dahsyat dari kenyataan riil empirik sebenarnya. Hyper-reality menjadi kekuatan media untuk menaikkan rating program.

Terorisme bukanlah isu baru. Ia selalu terjadi seiring kemajuan dan dinamika peradaban manusia. Ia mulai menyeruak kembali ke permukaan wacana publik dunia setelah terjadinya peristiwa menggemparkan di gedung World Trade Center (WTC) di Amerika Serikat pada 11 September 2001 silam. Amerika mengklaim Osama bin Laden (pemimpin Al-Qaedah) yang mengotaki serangan ini. Insiden dehuman ini akhirnya menjadi isu global hampir semua negara di dunia termasuk Indonesia. Muncullah kesadaran universal untuk menggalang kerja sama melakukan eliminasi atas terorisme.

Masyarakat Indonesia melalui pernyataan politis maupun kampanye media massa, ikut mendukung aksi eliminasi terhadap terorisme global itu sebagai ikhtiar menciptakan tatanan dunia yang selaras, damai, dan harmonis. Pembunuhan massal di Amerika, menurut Collin Powel, telah mempersatukan banyak bangsa di dunia ini untuk berjuang bersama-sama melawan terorisme internasional (Jakarta-US Embassy, n.d.). Dunia perlu bekerja sama karena terorisme apalagi atas nama agama apa pun merusakkan potret kedamaian ideal di dunia.

Sebenarnya terorisme atas nama agama hampir terjadi di setiap agama. Karena penghayatan iman dan agama yang eksklusivistik cenderung mengabaikan nilai-nilai inklusivistik dan transparansi. Agama di salah satu sisi menjadi kekuatan yang positif namun pada saat yang sama dapat menjadi kekuatan negatif-merusak dengan daya indoktrinatifnya yang mampu merusakkan secara efektif. Sering kali atas nama agama dan Tuhan, orang beragama apa saja bisa melakukan tindakan tidak etis 
untuk merusakkan kenyataan sosial dunia. Ini sebuah petaka atau katastrofe yang perlu disadari bersama oleh semua pihak, termasuk oleh pemimpin setiap agama masing-masing di dunia.

\section{Formalisme Agama yang Ortodoksif}

Agama berkaitan erat dengan indikator ekspresif yang kental di dalamnya. Salah satu ekspresi agama tampil dalam wujud ritual yang mengikat para anggota penganutnya. Namun sering kali para penganut agama hanya berorientasi pada ritus sebagai sarana untuk penguatan identitas bersama saja. Apalagi ritus itu hanya dilakukan secara formal tanpa adanya komitmen relevansi sosial aktual. Jika demikian, agama hanya berorientasi ritual dan kehilangan sentuhannya pada dunia nyata. Ini tentu gejala yang tidak bijak dalam konkteks harmoni hidup bersama.

Formalisme agama yang kaku (ortodoksi) didukung oleh penghayatan doktrin yang kaku, membuat orang-orang beragama terbelenggu dalam sikap tertutup ekstrem. Ini akan sulit bagi upaya penciptaan harmoni sosial menuju perdamaian bersama. Ritualisme memang penting untuk menimba energi rohani dalam hidup pribadi, namun perlu ditindaklanjuti dalam praktik sosial nyata yang terbuka pada orang lain. Jadi masih saja ada hambatan formalisme agama yang kaku dalam penghayatan keagamaan banyak orang yang mengaku beragama. Ini tentu hal yang memprihatinkan.

Hampir dalam setiap agama ada bahkan pernah ada praktik formalisme agama seperti ini. Baik dalam Islam dan Kristen, data sejarah menunjukkan adanya indikator itu. Formalisme agama menciptakan ruang gerak yang kaku dan formal di dalam agama sehingga menutup kemungkinan bagi adanya dialog dan kerja sama dengan agama lain. Praktik formalisme dalam semua agama manusia merupakan hal yang kontraproduktif bagi masa depan hubungan antaragama yang makin ideal.

\section{Sintesis Agama: Menciptakan Perdamaian Global}

\section{Memperkuat Integrasi Sosial Masyarakat (Perspektif Agama-Agama)}

Arah penguatan integrasi sosial yakni kondisi masyarakat yang harmonis dalam konteks pluralisme suku, agama, ras, antargolongan (SARA). Jika konflik agama dan fenomena intoleransi terjadi karena formalisme agama yang keliru, dibutuhkan sebuah kontruksi paradigma ideologis baru untuk menata kehidupan dunia yang lebih ideal dalam agama-agama menuju kesatuan dan persatuan dalam keberbedaan. Penguatan integrasi sosial masyarakat ini dapat ditilik dari beberapa agama di Indonesia, di antaranya: Islam, Kristen (Katolik dan Protestan), dan Hindu.

Sebenarnya ide integrasi sosial sudah menjadi perhatian banyak pemikir/teolog agama. Noer (2011) (perspektif Islam) membidik formalisme agama tidak cukup memadai untuk membangun karakter umat beragama yang ideal. Ia merekomendasikan sebuah paradigma pendidikan spiritual yang holistik terhadap seluruh anggota masyarakat penganut agama. Dibutuhkan terobosan baru bernama pendidikan spiritual. Pendidikan spiritual dilihat sebagai perjuangan terberat yang menuntut setiap penganut agama melawan, memerangi, dan bahkan meninggalkan dirinya, jiwanya, egonya atau keakuannya. Sepulang dari Perang Badar, Nabi Muhammad mengatakan bahwa kita telah kembali dari jihad yang kecil, namun jihad yang lebih besar adalah melawan egoisme diri sendiri/jihad nafs. Ini artinya Islam memiliki wawasan yang terbuka pada persatuan dan mendukung ide harmoni sosial dalam perbedaan keyakinan.

Dari perspektif Hindu, Suratnaya (2011) menegaskan Kitab Veda yang mendukung harmoni dan integrasi sosial: "Berkumpullah, berbicara, dan bersatu dalam pikiran, seperti para Deva dahulu bersatu dalam persembahan. Hendaknya tujuanmu sama dalam musyawarah, bawalah pikiranmu ke dalam hasrat persatuan, karena tujuan yang sama itu telah Kugariskan kepadamu, hendaknya pikiranmu satu, agar engkau dapat hidup dalam kebahagiaan,” (Rg. Veda X. 191.2, 3, 4). 
Dari Kristianisme (Katolik dan Protestan) ada spirit baru berupa keterbukaan pada kesatuan atau harmoni sosial dalam konteks perbedaan agama dan keyakinan iman. Agama Kristiani mengajarkan bahasa kasih berupa cinta yang universal untuk semua orang dari latar belakang bangsa dan agama manapun.

Khusus dari Katolik (Romo Beny Susetyo), mengangkat relevansi Konsili Vatikan II bagi harmoni sosial masyarakat dunia dewasa ini. Menurut Susetyo (2011), arah dasar Gereja yang sebelumnya menghayati pepatah klasik "Extra Ecclesia Nullan Salus" (di luar Gereja tidak ada keselamatan) melalui Konsili Firense (1438-1455) berubah sejak Vatikan II. Pasca Konsili Vatikan II (1962-1965) Gereja menunjukkan sikap keterbukaan terhadap agama lain. Gereja mengakui orang di luar Gereja pun mengalami keselamatan (Lumen Gentium No. 15, 16); agama-agama bukan Kristiani seperti Yahudi, Islam, Budhisme, Hinduisme harus dihormati dan segala yang suci menurut mereka harus diakui (Nostra Aetate); gereja wajib memaklumkan Injil ke seluruh dunia namun melarang segala cara yang tidak wajar (Ad Gentes no. 13); gereja mengakui hak atas kebebasan beragama (Dignitates Humanae). Jadi semangat keterbukaan inklusif di dalam tradisi Kristen tidak teragukan lagi. Semua agama mengajarkan kesatuan dan persatuan menuju harmoni dan integrasi sosial yang makin kukuh-kuat.

\section{Membangun Hubungan Kerja Sama Lintas Agama}

Kerja sama lintas agama merupakan sebuah usaha yang lebih luas daripada sekadar toleransi. Jika toleransi lebih cenderung pada sikap menghargai orang lain dalam berpikir dan bertindak, kerja sama lebih menekankan pada aktivitas/kegiatan konkret-nyata yang dibuat oleh para penganut agama lintas batas dalam nuansa semangat toleransi. Kerja sama yakni kegiatan bersama yang dilakukan oleh kelompok penganut agama untuk memajukan kehidupan sosial masyarakat yang sejahtera lahiriahbatiniah, jasmani-rohani, fisik-spiritual, badan-jiwa.

Kerja sama yang dimaksud perlu mencakup berbagai dimensi kehidupan manusia secara holistik mulai dari aspek ekonomi, sosial, politik, hukum hingga perdamaian dan keamanan sosial. Beberapa isu kritis dalam kerja sama antarumat beragama bisa dilakukan melalui kegiatan sosial kampanye melawan ketidakadilan ekonomi, kesenjangan sosial, antikorupsi dan KKN, serta upaya penegakan keadilan hukum. Semua hal ini berkaitan dengan usaha untuk menciptakan masyarakat yang harmonis dan serasi.

Kerja sama hanya akan berlangsung baik jika setiap pemeluk agama terbuka pada sesama penganut agama lain, menerima sesama pemeluk agama lain sebagai saudara secara tulus-ikhlas. Hal ini mengandaikan tiadanya rasa curiga, prasangka, dan stereotip negatif pada pemeluk agama lain. Perlakuan streotip negatif pada sesama agama lain hanya akan menciptakan masalah dalam hubungan antaragama. Sehingga pada akhirnya makin memperkukuh sikap eksklusif yang menghambat tumbuhnya inklusivisme dan pluralisme.

\section{Menegakkan Dimensi Etis-Religius menuju Perdamaian Dunia}

Substansi yang melekat erat pada setiap ajaran agama mengamanahkan secara eksplisit maupun implisit adanya pesan etis-moral penghayatan agama dalam realitas kehidupan sehari-hari. Bahwa agama ada untuk memperbaiki dan mengontrol perbuatan manusia dalam hidup sosial adalah kebenaran yang tidak dapat disangkal. Karena itulah semua agama perlu menanamkan kesadaran diri selalu pada dirinya bahwa penegakan dimensi etis-religius merupakan sesuatu sine qua non (yang mutlak) dihayati dalam seluruh dinamika kiprah agama di dalam alam semesta ini.

Tentu kita diingatkan bahwa menegakkan dimensi etis-religius agama tidak harus menggunakan hal-hal yang bertentangan dengan nilai-nilai kemanusiaan, etika, dan hukum. Hal ini 
penting disadari agar jangan sampai usaha menegakkan dimensi etis-agama ini terjebak pada tindakantindakan machiavelistis alias tujuan menghalalkan segala cara. Tetap harus disadari bahwa menegakkan dimensi etis-religius perlu ditempuh dengan cara-cara yang santun, etis, bermoral, dan manusiawi. Hal itu disebabkan sering orang bisa saja atas nama moral untuk melakukan hal-hal yang melawan moral itu sendiri. Ini tentu hal yang tidak ideal dalam konteks usaha menegakkan etikareligius.

Menegakkan dimensi etis-religius dalam tatanan sosial, perlu disadari untuk mengedepankan cara-cara yang baik, terpuji dan bermartabat. Tidak bisa dihayati lagi adagium (peribahasa) klasik orang Latin "ci vis pacem, para bellum", jika mau damai bersiaplah untuk berperang. Filosofi atau cara pandang keliru seperti ini perlu ditinggalkan. Menghayati cara pandang seperti ini merupakan sesuatu yang anakronistik, alias ketinggalan zaman dan kontra peradaban. Jika mau damai, bersiaplah untuk berdamai. Jika mau memperjuangkan kebaikan (etika-religius), perjuangkanlah itu juga dengan cara-cara yang baik. Bukan sebaliknya, dengan cara-cara yang tidak beradab, tidak santun dan tidak terpuji.

\section{Berpikir Kritis dalam Menghayati Agama}

Selain sikap etis, penganut agama juga perlu mengedepankan sikap kritis-rasional. Kemampuan untuk berpikir kritis dibutuhkan dalam menghayati agama secara benar. Berpikir kritis berarti kita melatih untuk menjadi seorang pemikir yang bebas, mandiri, kreatif, reflektif, koheren, dan logis sehingga seorang pribadi mampu mencapai tingkat pemahaman/pengertian yang tinggi dan mampu menyerap makna dari suatu objek yang dipikirkan (Fios, 2013).

Dalam konteks berpikir kritis dalam penghayatan agama, seorang penganut agama tidak boleh menghayati imannya secara buta. Hal ini hanya akan membuat penganut agama bertindak irasional dalam hal-hal yang negatif-destruktif. Penganut agama perlu terbuka untuk melatih cara berpikir kritis dalam menghayati agama dengan cara menyaring sikap, perilaku, tindakan, dan cara pikir yang sesat seperti prasangka negatif, curiga, eksklusif yang bisa makin mendisharmoni hubungan antarmanusia (penganut agama berbeda). Iman agama perlu bantuan akal budi yang benar agar penghayatan agama tidak terjebak dalam praktik agama yang keliru dan salah.

Berpikir kritis perlu dijalankan satu paket dengan penghayatan emosi keagamaan yang berimbang. Sehingga hasil akhirnya bisa membawa manfaat positif dalam penghayatan iman yang baik (etis) dan benar (kritis-rasional). Jika dua hal ini dijalankan secara konsisten, para penganut agama dikatakan menghayati imannya secara bijaksana. Tentu persoalan negativistik dalam agama pun bisa dieliminasi atau setidak-tidaknya diminimalkan seoptimal mungkin.

\section{Dari Benci menuju Cinta}

Kondisi ideal tertinggi semua agama yakni membawa manusia hidup dalam suasana cinta, suasana kasih sayang, suasana kebahagiaan, suasana surga. Kiprah agama selalu dan di mana saja perlu sadar untuk terus menggaungkan semangat etis-positif ini. Itu artinya agama perlu terus membersihkan dirinya dari berbagai sikap destruktif-negatif yang mempolusikan peran konstruktifpositif agama dalam realitas masyarakat. Otokritik menjadi suatu keniscayaan bagi agama dan para penganutnya.

Daripada menggelorakan semangat antipati dan benci antara sesama pemeluk agama, lebih baik mengobarkan cinta kasih antarsesama manusia. Inilah saatnya umat mentransformasi agama dari model penghayatan yang negatif (benci) menuju model penghayatan agama yang positif (cinta kasih). Tanggung jawab mengobarkan semangat positivisme agama perlu disadari selalu oleh semua entitas dalam agama: penganut, pemimpin, dan tokoh agama. Kesatuan penghayatan sisi agama yang positif dari benci menuju cinta ini perlu dihayati terus menerus sebagai sebuah proses yang tidak pernah usai. 
Artinya, penganut agama dalam hidupnya perlu selalu berjuang untuk mengatasi kekurangan dan kelemahan manusiawi dalam menghayati iman keagamannya secara benar menuju kesempurnaan hakiki. Inilah tanggung jawab religius-spiritual yang tak pernah selesai dalam dinamika religiusspiritual kelompok penganut agama di dunia ini.

\section{SIMPULAN}

Agama merupakan suatu realitas sosial yang fenomenal di masyarakat dunia manusia. Hingga kini agama masih merupakan kekuatan yang patut diperhitungkan dalam peta politik dan sosial budaya mondial. Agama bisa menjadi kekuatan yang membelenggu dan menghambat perkembangan peradaban manusia jika para penganutnya tidak menghayati agama secara benar dan bermartabat. Jika demikian, agama hanya akan menjadi kekuatan yang kontra terhadap perkembangan peradaban dan kemajuan manusia dari waktu ke waktu. Kiprah agama yang sejati seharusnya bermuara pada penciptaan masyarakat dunia yang aman dan damai tempat berseminya cinta dan persaudaraan universal di dalam tatanan dunia. Hal ini hanya mungkin jika penganut agama menghayati agama sebagai kekuatan positif yang membebaskan manusia dari berbagai hal yang destruktifkontraproduktif dalam masyarakat.

Kiprah agama perlu diproyeksikan pada usaha memajukan dunia sosial dan masyarakat manusia yang berdiri di atas nilai-nilai kemanusiaan, keadilan, kedamaian, persaudaraan, cinta, etika, dan kebijaksanaan sosial. Hanya melalui nilai-nilai positif inilah agama bisa selalu menjadi kekuatan yang membebaskan di dalam masyarakat global. Kiprah ini pula yang memberikan makna dan arti pada eksistensi agama di dalam tatanan dunia. Jika tidak, agama tidak memiliki relevansi aktual dalam konteks global. Kehadirannya bisa dianggap sia-sia atau nihil jika tidak berupaya menciptakan perdamaian dunia hic et nunc (kini dan di sini). Penganut agama masih harus berjuang ekstra keras meyakinkan dunia bahwa agama masih menjadi elemen penting di dalam masyarakat dunia ini. Jika tidak, cepat atau lambat agama akan ditinggalkan banyak orang karena merasa frustrasi pada penganut agama yang masih saja bertindak usil dan memuakkan dalam menghayati iman keagamaannya.

\section{DAFTAR PUSTAKA}

Bagus, L. (2005). Kamus Filsafat. Jakarta: Gramedia.

Calvin S. H., \& Lindzey, G. (1993). Teori-Teori Holistik (Organismik-Fenomenologis). Alih bahasa: A. Supratiknya. Yogyakarta: Kanisius.

Fios, F. (2013). Pengantar Filsafat Ilmu dan Logika. Jakarta: Salemba Humanika.

Jakarta-US Embassy. (n.d.). Diakses dari http://jakarta.ussembassy.gov

Noer, K. A. (2011). Membina Kerukunan Beragama melalui Spiritualitas Islam. Workshop Kerukunan Beragama Dosen-Dosen Pendidikan Agama se-DKI Jakarta, 18-19 November 2011.

Prawironegoro, D. (2010). Filsafat Ilmu. Jakarta: Nusantara Consulting.

Religious Tolerance. (n.d.). Diakses dari http://www.religioustolerance.org 
Storig, H. J. (1995). Kleine Weltgesichhichte der Philosophia. Stuttgart: Stuttgart Press.

Suratnaya, D. K. (2011). Pengembangan Kerukunan Beragama Perspektif Hindu Dharma. Workshop Kerukunan Beragama Dosen-Dosen Pendidikan Agama se-DKI Jakarta, 18- 19 November 2011.

Suseno, F. M. (2012). Panutan, Integritas dan Karakter. dalam Seminar di Binus University, 31 Mei, $1-16$.

Susetyo, B. (2011). Kerukunan Beragama dalam Perspektif Katolik. Workshop Kerukunan Beragama Dosen-Dosen Pendidikan Agama se-DKI Jakarta, 18-19 November 2011.

Woi, A. (2001). Agama, Integrasi dan Perdamaian. Maumere: STFK Ledalero. 